\title{
Susceptibility of juvenile Macrobrachium rosenbergii to different doses of high and low virulence strains of white spot syndrome virus (WSSV)
}

\author{
Mathias Corteel ${ }^{1}$, João J. Dantas-Lima ${ }^{1}$, Vo Van Tuan ${ }^{1}$, Khuong Van Thuong ${ }^{1}$, \\ Mathieu Wille ${ }^{2}$, Victoria Alday-Sanz ${ }^{3}$, Maurice B. Pensaert ${ }^{1}$, Patrick Sorgeloos ${ }^{2}$, \\ Hans J. Nauwynck ${ }^{1, *}$

\footnotetext{
${ }^{1}$ Laboratory of Virology, Faculty of Veterinary Medicine, Ghent University, 9820 Merelbeke, Belgium

${ }^{2}$ Laboratory of Aquaculture \& Artemia Reference Center, Faculty of Bioscience Engineering, Ghent University, 9000 Gent, Belgium

${ }^{3}$ Pescanova, 08010 Barcelona, Spain
}

\begin{abstract}
As some literature on the susceptibility of different life stages of Macrobrachium rosenbergii to white spot syndrome virus (WSSV) is conflicting, the pathogenesis, infectivity and pathogenicity of 2 WSSV strains (Thai-1 and Viet) were investigated here in juveniles using conditions standardized for Penaeus vannamei. As with $P$. vannamei, juvenile $M$. rosenbergii $(2$ to $5 \mathrm{~g})$ injected with a low dose of WSSV-Thai-1 or a high dose of WSSV-Viet developed comparable clinical pathology and numbers of infected cells within 1 to $2 \mathrm{~d}$ post-infection. In contrast, a low dose of WSSV-Viet capable of causing mortality in $P$. vannamei resulted in no detectable infection in $M$. rosenbergii. Mean prawn infectious dose $50 \%$ endpoints $\left(\mathrm{PID}_{50} \mathrm{ml}^{-1}\right.$ ) determined in M. rosenbergii were in the order of 100-fold higher for WSSV-Thai-1 $\left(10^{5.3 \pm 0.4} \mathrm{PID}_{50} \mathrm{ml}^{-1}\right)$ than for WSSVViet $\left(10^{3.2 \pm 0.2} \mathrm{PID}_{50} \mathrm{ml}^{-1}\right)$, with each of these being about 20 -fold and 400 -fold lower, respectively, than found previously in $P$. vannamei. The median lethal dose $\left(\mathrm{LD}_{50} \mathrm{ml}^{-1}\right)$ determined in $M$. rosenbergii was also far higher ( 1000-fold) for WSSV-Thai-1 $\left(10^{5.4 \pm 0.4} \mathrm{LD}_{50} \mathrm{ml}^{-1}\right)$ than for WSSV-Viet $\left(10^{2.3 \pm 0.3} \mathrm{LD}_{50} \mathrm{ml}^{-1}\right)$. Based on these data, it is clear that juvenile $M$. rosenbergii are susceptible to WSSV infection, disease and mortality. In comparison to $P$. vannamei, however, juvenile $M$. rosenbergii appear more capable of resisting infection and disease, particularly in the case of a WSSV strain with lower apparent virulence.
\end{abstract}

KEY WORDS: White spot syndrome virus · WSSV $\cdot$ Macrobrachium rosenbergii $\cdot$ Resistance Susceptibility

Resale or republication not permitted without written consent of the publisher

\section{INTRODUCTION}

White spot syndrome virus (WSSV) infects a wide spectrum of crustaceans and is one of the most important pathogens of cultured penaeid shrimp. Over 80 species, including freshwater prawns, crayfish, lobsters and crabs, have been described to be hosts or carriers of WSSV (Escobedo-Bonilla et al. 2008). Crustaceans that can carry WSSV pose a potential risk of transmitting infection and disease to cultured shrimp (Rajendran et al. 1999, Flegel 2007).

Macrobrachium rosenbergii is the most widely cultured freshwater prawn species worldwide (New 2002) with annual yields exceeding $30000 \mathrm{t}$ (FAO 2009). Compared to penaeid shrimp, it is generally considered less prone to disease in culture (Bonami \& Widada 2011). With respect to WSSV, however, there have been some conflicting reports on the suscepti- 
bility of different $M$. rosenbergii life stages. For example, some studies have reported larval and postlarval stages to be susceptible but older prawns to be quite refractive to acute infection and mortality (Lo et al. 1996, Peng et al. 1998, Pramod Kiran et al. 2002). Indeed, in a comparative study including 2 other Macrobrachium sp. ( $M$. idella and $M$. lamerrae) as well as Penaeus monodon, $M$. rosenbergii juveniles ( 1 to $2 \mathrm{~g}$ ) and adults ( 5 to $7 \mathrm{~g}$ ) were confirmed to resist disease and mortality when challenged with WSSV by water-borne exposure, tissue ingestion and intramuscular injection (Sahul Hameed et al. 2000). Follow-up studies showed WSSV infection to be transient, diminishing within a few days post-challenge (Waikhom et al. 2006, Yoganandhan et al. 2006). PCR tracking of WSSV loads in $M$. rosenbergii adults challenged by injection has also shown that the majority of WSSV is cleared within $5 \mathrm{~d}$ post-challenge, after which time low levels of virus remained detectable in some organs for 25 to $50 \mathrm{~d}$ (Sarathi et al. 2008). Although not investigated in detail, there is some evidence to suggest hemagglutinins or lectins are involved in the process that protects $M$. rosenbergii against WSSV (Pais et al. 2007).

In the present study, the pathogenicity of WSSV strains of high (Thai-1) and low (Viet) virulence for penaeid shrimp (Rahman et al. 2008) was investigated in juvenile Macrobrachium rosenbergii under standardized conditions used to determine their pathogenicity for Penaeus vannamei. Tracking of numbers of infected cells in different organs over time in prawns injected with high and low doses of each strain and determinations of prawn infectious dose $\left(\mathrm{PID}_{50}\right)$ and lethal dose $\left(\mathrm{LD}_{50}\right) 50 \%$ end-points for the 2 WSSV strains confirmed the greater resistance of juvenile $M$. rosenbergii to infection and disease compared to $P$. Vannamei, especially for the low virulence strain.

\section{MATERIALS AND METHODS}

\section{Prawns}

Macrobrachium rosenbergii were bred and reared using standard practices in the aquarium facilities at Ghent University, Belgium (New 2002). Prawns used were 3rd generation offspring from broodstock imported from Thailand. Juvenile $M$. rosenbergii (2 to $5 \mathrm{~g}$ ) were fed commercial penaeid shrimp feed pellets at a rate of $2.5 \%$ of their weight per day and maintained at $27 \pm 0.5^{\circ} \mathrm{C}$ water temperature.

\section{WSSV}

The WSSV strains used to challenge Macrobrachium rosenbergii originated from diseased Penaeus monodon from either Thailand in 1996 (WSSV-Thai1) or Vietnam in 2003 (WSSV-Viet) (Rahman et al. 2008). WSSV-Thai-1 had been passaged once in Pacifastacus leniusculus (Jiravanichpaisal et al. 2001) and WSSV-Viet had been passaged once in Cherax quadricarinatus. Crayfish gill homogenates containing WSSV-Thai-1 (from P. Jiravanichpaisal and K. Söderhäll, Uppsala University, Sweden) or WSSV-Viet (from Research Institute for Aquaculture no. 2, Ho Chi Minh City, Vietnam) were passaged in specific pathogen-free (SPF) Penaeus vannamei to produce inocula and determine infectious titers as described previously (Escobedo-Bonilla et al. 2005). Shrimp infectious dose $50 \%$ endpoint $\left(\mathrm{SID}_{50}\right) \mathrm{ml}^{-1}$ titers were $10^{6.6}$ and $10^{5.8}$ for WSSV-Thai-1 and WSSV-Viet, respectively. Inocula were stored at $-70^{\circ} \mathrm{C}$ and dilutions used to challenge $M$. rosenbergii were prepared in ice-cold phosphate-buffered saline (PBS).

\section{Challenge protocols}

In all bioassays, WSSV inoculum (50 $\mu$ l) was injected into muscle at the junction between the 3rd and 4th abdominal segments. Methods to assess WSSV pathogenesis followed closely those described by Rahman et al. (2008). In brief, 140 Macrobrachium rosenbergii juveniles ( 2 to $5 \mathrm{~g}$ ) were stocked into $50 \mathrm{l}$ aquaria (5 prawns per aquarium), each equipped with a water filter and heater. Based on $\mathrm{SID}_{50} \mathrm{ml}^{-1}$ titers, each WSSV strain was injected into 30 prawns at either a low dose (LD, $30 \mathrm{SID}_{50}$ ) or a high dose (HD, 10000 SID $_{50}$ ). At 12, 24, 36, 48, 72 and $120 \mathrm{~h}$ post injection (hpi), prawns surviving in 1 tank were euthanized to collect and process cephalothorax tissue for immunohistochemistry (IHC). Prior to sampling, prawns were observed for gross disease signs and mortality was recorded. A group of 5 prawns was sampled at the beginning of the trial ( $0 \mathrm{hpi}$ ).

Bioassays to determine the PID $_{50}$ were performed essentially as described previously (Escobedo-Bonilla et al. 2005, 2006), except that the WSSV infectivity titer was determined at $48 \mathrm{hpi}$ instead of $120 \mathrm{hpi}$ based on when most prawns were found to be infected by indirect immunofluorescence (IIF). In brief, 5 prawns $(2 \mathrm{~g}$ ) in each of 3 replicate 101 aerated and covered plastic aquaria (15 prawns per dilution) were injected with 10-fold serial dilutions of either WSSV-Thai-1 $\left(10^{-1}\right.$ to $\left.10^{-6}\right)$ or WSSV-Viet (undiluted 
to $10^{-4}$ ). Prawns were examined at $12 \mathrm{~h}$ intervals for gross disease signs and at $48 \mathrm{hpi}$, all prawns were euthanized and cephalothoraxes were processed for IIF.

The challenge procedure used to determine infectivity was used similarly to determine the $\mathrm{LD}_{50}$, except that prawns $(2 \mathrm{~g})$ were maintained for longer (5 d). Prawns were examined at $12 \mathrm{~h}$ intervals for gross disease signs and to record deaths and moribund prawns (considered as dead). At $120 \mathrm{hpi}$, all surviving prawns were euthanized to process cephalothoraxes for IIF.

\section{IHC}

Cephalothoraxes of moribund and euthanized prawns were processed for IHC to detect WSSVinfected cells using procedures described previously (Escobedo-Bonilla et al. 2007). As in the study of Penaeus vannamei (Rahman et al. 2008), WSSVinfected cell numbers in gills, hematopoietic tissue and cuticular epithelium of stomach and body wall were quantified by light microscopy at 400× magnification. For gills and hematopoietic tissue, infected cells in 5 randomly selected fields were counted and expressed as cells $\mathrm{mm}^{-2}$. For cuticular epithelium, both WSSV-infected and uninfected cells were counted in 5 fields selected at random and expressed as average percentage (\%) infected cells. Differences in numbers of infected cells were tested for significance using $t$-tests.

\section{IIF}

Cephalothoraxes of recently dead and euthanized prawns were processed for IIF to detect WSSV using procedures described previously (Escobedo-Bonilla et al. 2006).

\section{RESULTS}

\section{WSSV pathogenesis in Macrobrachium rosenbergii}

When injected with a low dose of WSSV-Thai-1, the number of Macrobrachium rosenbergii prawns displaying disease signs peaked at 48 hpi (all 5 prawns) and then declined, with none of the prawns displaying disease signs at 120 hpi (Table 1). Over this period, only 1 of 5 prawns became moribund at $48 \mathrm{hpi}$, and 2 of 5 prawns at $72 \mathrm{hpi}$. IHC analysis of gills, hematopoietic tissue and cuticular epithelium of stomach and body detected WSSV-infected cells in the majority of prawns sampled from 36 hpi onwards (Table 1). In the 3 prawns in which WSSV was detected at $120 \mathrm{hpi}$, infected cell numbers were lower than in prawns sampled at either $48 \mathrm{hpi}$ or 72 hpi. Except for at $24 \mathrm{hpi}$ ( $\mathrm{p}>0.05)$, infected cell numbers seen in organs of $M$. rosenbergii (Table 1) were not significantly different from numbers seen in comparable organs of $P$. vannamei challenged with the same dose of WSSV (Rahman et al. 2008)

When injected with a high dose of WSSV-Thai-1, the number of prawns displaying disease signs peaked similarly at $48 \mathrm{hpi}$ and declined thereafter very similarly to the low-dose challenge (Table 1). More moribund shrimp were evident at $36 \mathrm{hpi}$ and at 48 hpi ( 3 of 5), 72 hpi ( 2 of 5) and 120 hpi (1 of 5) compared to the low dose challenge. IHC also detected WSSV-infected cells earlier (2 of 5 prawns at $24 \mathrm{hpi}$ ) and in all prawns sampled thereafter. Similarly to the low dose of WSSV-Thai-1, WSSV-infected cell numbers increased from $24 \mathrm{hpi}$ to a maximum around 48 to $72 \mathrm{hpi}$ before declining to very low levels at $120 \mathrm{hpi}$ (Table 1, Fig. 1A). Curiously, except for hematopoietic tissue at 48 hpi ( $p<0.05)$, infected cell numbers did not differ significantly in any tissue type compared to those seen with the low dose WSSV-Thai-1 inoculum.

When injected with a low dose of WSSV-Viet, none of the prawns displayed gross disease signs, none died and no WSSV-infected cells were found by IHC analysis at any time point (Table 1, Fig. 1). At the high dose, however, 1 of 5 prawns showed disease signs at $24 \mathrm{hpi}$ and this increased to a maximum of 4 of 5 prawns at $36 \mathrm{hpi}$ and $48 \mathrm{hpi}$ before declining to no prawns at $120 \mathrm{hpi}$ (Table 1). Despite prawns showing disease signs, no deaths occurred prior to when prawns were sampled. WSSV-infected cells were first detected by IHC in low numbers at 36 hpi (12 hpi later than with WSSV-Thai-1) and numbers peaked at $48 \mathrm{hpi}$ before declining (Table 1, Fig. 1B). Infected cell numbers in gill tissues at $36 \mathrm{hpi}(5 \pm 9)$ and $72 \mathrm{hpi}$ $(18 \pm 29)$ were significantly lower $(p<0.05)$ than those seen at these times with WSSV-Thai-1 $(49 \pm 32$ and $157 \pm 94$, respectively), but at all other times there were no significant differences ( $p>0.05)$ across the tissues examined.

\section{Determination of the PID $_{50}$ of the WSSV strains}

Among groups of prawns injected with WSSVThai-1 inoculum diluted $10^{-1}$ to $10^{-6}$, those injected with $10^{-1}, 10^{-2}$ and $10^{-3}$ dilutions began to display disease signs from $24 \mathrm{hpi}$. Based on IIF detection of 
Table 1. Macrobrachium rosenbergii. Immunohistochemistry quantification of infected cell numbers in various organs of prawns ( $\mathrm{n}=5$ per time point) injected with either white spot syndrome virus (WSSV)-Thai-1 or WSSV-Viet. hpi: hours post injection

\begin{tabular}{|c|c|c|c|c|c|c|c|c|c|}
\hline \multirow{2}{*}{$\begin{array}{l}\text { WSSV } \\
\text { strain }\end{array}$} & \multirow[t]{2}{*}{ Dose } & \multirow[t]{2}{*}{ hpi } & \multirow[b]{2}{*}{$\begin{array}{l}\text { Disease } \\
\text { signs }\end{array}$} & \multicolumn{2}{|c|}{ - No. of prawns } & \multicolumn{4}{|c|}{-Average no. of infected cells in infected prawns } \\
\hline & & & & Mortality & $\begin{array}{c}\text { Infected cells } \\
\text { detected }\end{array}$ & $\begin{array}{c}\text { Gills } \\
\left(\mathrm{mm}^{-2}\right)\end{array}$ & $\begin{array}{c}\text { Stomach } \\
\text { epithelium (\%) }\end{array}$ & $\begin{array}{c}\text { Cuticular } \\
\text { epithelium (\%) }\end{array}$ & $\begin{array}{c}\text { Hematopoietic } \\
\text { tissue }\left(\mathrm{mm}^{-2}\right)\end{array}$ \\
\hline \multirow[t]{14}{*}{ Thai-1 } & \multirow[t]{7}{*}{ Low } & 0 & 0 & 0 & 0 & 0 & 0 & 0 & 0 \\
\hline & & 12 & 0 & 0 & 0 & 0 & 0 & 0 & 0 \\
\hline & & 24 & 1 & 0 & 0 & 0 & 0 & 0 & 0 \\
\hline & & 36 & 3 & 0 & 4 & $39 \pm 42$ & $2 \pm 4$ & $12 \pm 9$ & $23 \pm 15$ \\
\hline & & 48 & 5 & 1 & 5 & $129 \pm 149$ & $9 \pm 12$ & $19 \pm 21$ & $53 \pm 33$ \\
\hline & & 72 & 3 & 2 & 5 & $239 \pm 203$ & $29 \pm 13$ & $28 \pm 14$ & $15 \pm 16$ \\
\hline & & 120 & 0 & 0 & 3 & $1 \pm 3$ & $0.8 \pm 2$ & $3 \pm 5$ & 0 \\
\hline & \multirow{7}{*}{ High } & 0 & 0 & 0 & 0 & 0 & 0 & 0 & 0 \\
\hline & & 12 & 0 & 0 & 0 & 0 & 0 & 0 & 0 \\
\hline & & 24 & 2 & 0 & 2 & $7 \pm 7$ & $0.8 \pm 0.7$ & $0.6 \pm 0.4$ & $2.5 \pm 0.7$ \\
\hline & & 36 & 4 & 3 & 5 & $49 \pm 32$ & $10 \pm 8$ & $8 \pm 8$ & $22 \pm 20$ \\
\hline & & 48 & 5 & 3 & 5 & $199 \pm 270$ & $13 \pm 11$ & $14 \pm 13$ & $109 \pm 23$ \\
\hline & & 72 & 4 & 2 & 5 & $157 \pm 94$ & $20 \pm 5$ & $22 \pm 4$ & $37 \pm 24$ \\
\hline & & 120 & 2 & 1 & 5 & $3 \pm 3$ & $5 \pm 12$ & $6 \pm 2$ & $8.6 \pm 12$ \\
\hline \multirow[t]{14}{*}{ Viet } & \multirow[t]{7}{*}{ Low } & 0 & 0 & 0 & 0 & 0 & 0 & 0 & 0 \\
\hline & & 12 & 0 & 0 & 0 & 0 & 0 & 0 & 0 \\
\hline & & 24 & 0 & 0 & 0 & 0 & 0 & 0 & 0 \\
\hline & & 36 & 0 & 0 & 0 & 0 & 0 & 0 & 0 \\
\hline & & 48 & 0 & 0 & 0 & 0 & 0 & 0 & 0 \\
\hline & & 72 & 0 & 0 & 0 & 0 & 0 & 0 & 0 \\
\hline & & 120 & 0 & 0 & 0 & 0 & 0 & 0 & 0 \\
\hline & \multirow[t]{7}{*}{ High } & 0 & 0 & 0 & 0 & 0 & 0 & 0 & 0 \\
\hline & & 12 & 0 & 0 & 0 & 0 & 0 & 0 & 0 \\
\hline & & 24 & 1 & 0 & 0 & 0 & 0 & 0 & 0 \\
\hline & & 36 & 4 & 0 & 3 & $5 \pm 9$ & $9 \pm 11$ & $0.4 \pm 0.8$ & $7.5 \pm 9$ \\
\hline & & 48 & 4 & 0 & 5 & $53 \pm 33$ & $21 \pm 15$ & $30 \pm 20$ & $43 \pm 21$ \\
\hline & & 72 & 3 & 0 & 5 & $18 \pm 29$ & $7 \pm 6.5$ & $11 \pm 13$ & $10 \pm 19$ \\
\hline & & 120 & 0 & 0 & 2 & $15 \pm 17$ & $9 \pm 7$ & $2 \pm 4$ & $21 \pm 39$ \\
\hline
\end{tabular}

WSSV infection across prawns injected with the various inoculum dilutions and sacrificed at expected peak viremia (48 hpi), the geometric mean infectious dose determined for the 3 replicate prawn groups $\left(10^{5.05}, 10^{5.13}\right.$ and $\left.10^{5.80} \mathrm{PID}_{50} \mathrm{ml}^{-1}\right)$ was $10^{5.33 \pm 0.41}$ $\mathrm{PID}_{50} \mathrm{ml}^{-1}$ (Table 2). Among groups of prawns injected with WSSV-Viet inoculum diluted up to $10^{-4}$, all prawns injected with the undiluted and $10^{-1}$ diluted inoculum began to display disease signs from 24 hpi. Based on IIF detection of WSSV infection across prawns from all dilutions sacrificed at $48 \mathrm{hpi}$, the geometric mean infective titer determined from the 3 replicate groups $\left(10^{2.80}, 10^{3.13}\right.$ and $10^{3.67}$ PID $_{50}$ $\mathrm{ml}^{-1}$ ) was $10^{3.20 \pm 0.44} \mathrm{PID}_{50} \mathrm{ml}^{-1}$ (Table 2 ).

\section{Determination of the $\mathrm{LD}_{50}$ of the WSSV strains}

All prawns injected with $10^{-1}, 10^{-2}$ and $10^{-3}$ dilutions of WSSV-Thai-1 began to shown gross disease signs from 24 hpi. Among prawns injected with dilutions of $10^{-4}, 10^{-5}$ and $10^{-6}$, only those in which infected cells were evident when sampled at $120 \mathrm{hpi}$ showed disease signs from $24 \mathrm{hpi}$. Except for no white

Table 2. Macrobrachium rosenbergii. Numbers found to be infected at $48 \mathrm{~h}$ post-injection of 10 -fold dilutions $(\mathrm{n}=15$ per dilution) of either white spot syndrome virus (WSSV)-Thai-1 or WSSV-Viet as determined by indirect immunofluorescent staining. ND: not done

\begin{tabular}{|lcc|}
\hline \multirow{2}{*}{ Dilution } & \multicolumn{2}{c|}{ Prawns infected (\%) } \\
\cline { 2 - 3 } & WSSV-Thai-1 & WSSV-Viet \\
\hline Undiluted & ND & 100 \\
$10^{-1}$ & 100 & 100 \\
$10^{-2}$ & 100 & 40 \\
$10^{-3}$ & 100 & 0 \\
$10^{-4}$ & 53 & 0 \\
$10^{-5}$ & 7 & ND \\
$10^{-6}$ & 0 & ND \\
\hline
\end{tabular}



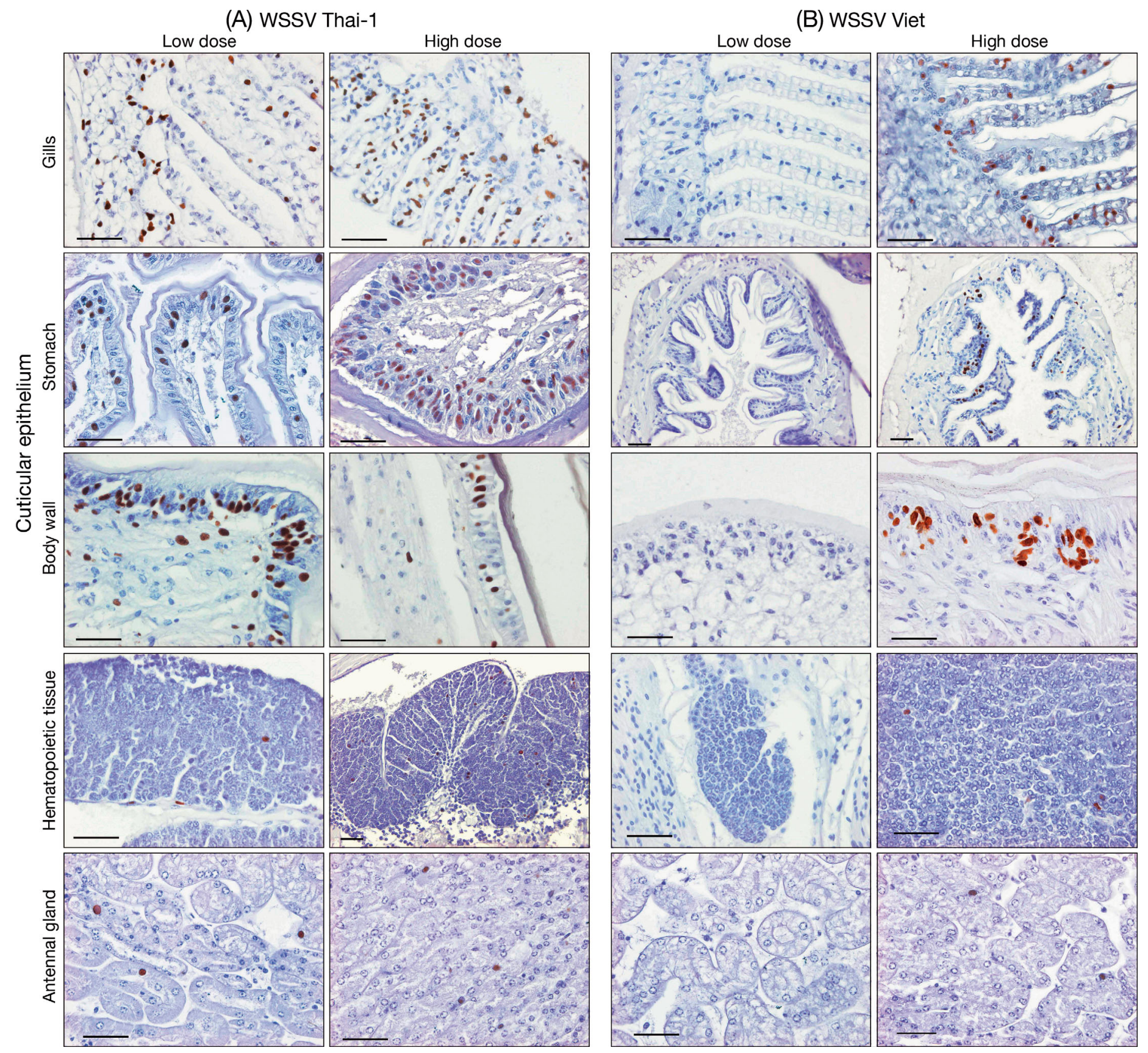

Fig. 1. Macrobrachium rosenbergii. Photomicrographs of gills, cuticular epithelia of the stomach and body wall, hematopoietic tissue, and antennal glands of juveniles sampled at $48 \mathrm{~h}$ post-injection with either 30 SID $_{50}$ (shrimp infectious dose $50 \%$ endpoint; low dose) or 10000 SID $_{50}$ (high dose) of either (A) white spot syndrome virus (WSSV)-Thai-1 or (B) WSSV-Viet. Infected cells were detected by immunohistochemistry using a VP28-specific monoclonal antibody. Scale bars $=50 \mu \mathrm{m}$

spots becoming evident in cuticle, disease signs were comparable to those seen in penaeid shrimp and included anorexia, lethargy and whitening of the body. Deaths occurred from 48 hpi onwards and the $\mathrm{LD}_{50}$ determined when the bioassay was terminated (120 hpi) for the 3 replicate groups of prawns $\left(10^{5.51}, 10^{5.14}\right.$ and $10^{5.48} \mathrm{LD}_{50} \mathrm{ml}^{-1}$ ) was $10^{5.38 \pm 0.21} \mathrm{LD}_{50} \mathrm{ml}^{-1}$.
All prawns injected with undiluted and $10^{-1}$ diluted WSSV-Viet began to show gross disease signs from $24 \mathrm{hpi}$. Among prawns injected with the $10^{-2}$ dilution, only those in which infected cells were evident when sampled at $120 \mathrm{hpi} \mathrm{showed} \mathrm{disease} \mathrm{signs} \mathrm{from} 24 \mathrm{hpi}$. Deaths occurred from $48 \mathrm{hpi}$ onwards and the $\mathrm{LD}_{50}$ determined when the bioassay was terminated (120 hpi) 
for the 3 replicate groups of prawns $\left(10^{2.00}, 10^{2.50}\right.$ and $10^{2.30} \mathrm{LD}_{50} \mathrm{ml}^{-1}$ ) was $10^{2.27 \pm 0.25} \mathrm{LD}_{50} \mathrm{ml}^{-1}$. A reduced $\mathrm{LD}_{50}$ compared to $\mathrm{PID}_{50}$ for prawns injected with the WSSV-Viet strain was indicative of its lower relative virulence predicted from bioassays in penaeid shrimp.

\section{DISCUSSION}

Some challenge experiments have reported juvenile and adult life stages of Macrobrachium rosenbergii to be quite refractive to WSSV infection (Sahul Hameed et al. 2000, Waikhom et al. 2006, Yoganandhan et al. 2006). However, in the present study, with bioassays using high and low virulence strains of WSSV, juvenile (2 to $5 \mathrm{~g}$ ) $M$. rosenbergii were found to readily support WSSV replication and succumb to disease and mortality. These data concur with alternative findings of higher infection levels and mortality occurring in earlier life stages (larvae and juveniles) than in adults (Lo et al. 1996, Peng et al. 1998, Rajendran et al. 1999, Pramod Kiran et al. 2002). While the differences in clinical outcomes with juvenile $M$. rosenbergii remain to be determined, possibilities include differences in $M$. rosenbergii age and origin, stress factors such as water temperature, and dose and virulence of the WSSV strain used. In examining WSSV strain virulence and dose factors in the bioassays reported here, 18.6-fold more WSSVThai-1 virus and 398-fold more WSSV-Viet virus was found to be required to establish infection in juvenile M. rosenbergii compared to Penaeus vannamei shrimp (Escobedo-Bonilla et al. 2005). These data indicate clearly that higher doses of WSSV are needed to establish infection in $M$. rosenbergii compared to shrimp, and that the WSSV strain origin can affect what dose is required for it to be capable of causing disease and mortality.

While both WSSV-Thai-1 and WSSV-Viet originated from diseased Penaeus monodon, each had been passaged through different crayfish species before being passaged through SPF $P$. vannamei to prepare the inocula used to challenge juvenile $M$. rosenbergii. It is possible that passage through the different crayfish species had some role in determining the virulence of the inocula. However, as the double-stranded DNA genome of WSSV evolves quite slowly (Zwart et al. 2010), virulence differences appear more likely to be inherent to each strain rather than a factor of their recent passage history.

Published bioassays with Macrobrachium rosenbergii have used various, often poorly described conditions and water temperatures ranging between 18 and $32^{\circ} \mathrm{C}$. It is quite possible that water temperature, which is known to affect WSSV replication (Rahman et al. 2006), had a major impact on the clinical and virological outcome. Here the water temperature was standardized to $27^{\circ} \mathrm{C}$, as this is optimal for replication of the WSSV-Thai-1 and WSSV-Viet strains in Penaeus vannamei (Rahman et al. 2006, 2007).

IHC detection of infected cells in cephalothorax tissues of Macrobrachium rosenbergii showed WSSV to replicate in the same target organs as found in Penaeus vannamei (Escobedo-Bonilla et al. 2007, Rahman et al. 2008), with the exception of the lymphoid organ for which no equivalent organ has been described in $M$. rosenbergii (P. Sithigorngul pers. comm.). Apart from the detection of infected cells being delayed from 24 to $36 \mathrm{hpi}$ in $M$. rosenbergii compared to $P$. vannamei challenged with a low dose of WSSV-Thai-1, their numbers did not differ significantly across the organs examined. Indeed there were few significant differences between infected cell numbers seen in any organs at any times following challenge with either low or high doses of WSSVThai-1 and a high dose of WSSV-Viet. However, in contrast to this as well as observations in $P$. vannamei, no infected cells were detected in any $M$. rosenbergii challenged with a low dose of WSSVViet.

Similarities in infected cell numbers seen in juvenile Macrobrachium rosenbergii challenged with high/low doses of WSSV-Thai-1 and a high dose of WSSV-Viet are confounding considering the differences in clinical outcomes. However, fewer infected gill cells were apparent with WSSV-Viet than with WSSV-Thai-1, which supports the hypothesis that gill infection levels provide a good barometer of clinical outcomes in shrimp (Rahman et al. 2008). Consistent with previous observations of a transitory viremic period in which disease signs and WSSV are readily detectable (Sahul Hameed et al. 2000, Waikhom et al. 2006, Yoganandhan et al. 2006, Sarathi et al. 2008), there was a general trend of falling numbers of infected cells in $M$. rosenbergii between 3 and 5 d post-challenge. More pronounced clearance effects appear to occur in challenged adult prawns (Sahul Hameed et al. 2000, Sarathi et al. 2008), and infection during the first couple of days following challenge has been tracked by immunedetection of the WSSV VP28 protein (Yoganandhan et al. 2006).

The mechanism by which WSSV infection is cleared by Macrobrachium rosenbergii remains a mystery that, if solved, could help devise strategies to protect cultured shrimp species. WSSV challenge 
affects levels of prophenoloxidase (proPO), superoxide anion, superoxide dismutase, total hemocyte count and clotting time, factors generally involved in antibacterial defense responses (Sarathi et al. 2008). There is evidence to suggest some role for proPO in defending non-crustacean invertebrates against viruses (Shelby \& Popham 2006). However, the increases in proPO levels in hemolymph and melanized lesions of shrimp infected with Taura syndrome virus (Hasson et al. 1999, Song et al. 2003) do not occur in $M$. rosenbergii infected with WSSV. No hemocytic infiltrations, encapsulations or ectopic spheroids typical of bacterial or viral infections in penaeid shrimp occur in WSSV-infected M. rosenbergii (Sarathi et al. 2007), so direct hemocytemediated intervention appears unlikely.

Hemagglutinins or lectins in the hemolymph of Macrobrachium rosenbergii might be the reason for their greater tolerance for WSSV infection compared to Penaeus monodon (Pais et al. 2007). However, if they are, their mode of action must be far more effective than the C-type lectins stimulated in response to WSSV infection in highly susceptible shrimp (Luo et al. 2003, Ma et al. 2007, 2008, Wang et al. 2009, Zhao et al. 2009). Moreover, while lectins may have roles in defending both vertebrates and invertebrates against viruses as well as bacteria and fungi (Wang et al. 2009, Cerenius et al. 2010), their function relies on their carbohydrate recognition domains (Cambi et al. 2005). As none of the 5 major structural proteins of WSSV appear to be glycosylated (van Hulten et al. 2002, Wei et al. 2012), any direct interaction between lectins and WSSV seems unlikely.

Macrobrachium rosenbergii defense against WSSV involves some mechanism that actively clears most infected cells within a few days of challenge. However, as M. rosenbergii that survive WSSV challenge appear to maintain low levels of virus detectable only by nested-PCR (Peng et al. 1998), the clearance mechanism might be evaded or deactivated once infection loads reach levels that can be tolerated indefinitely.

In summary, data reported here confirm that juvenile Macrobrachium rosenbergii have lower susceptibility to infection and more effective mechanisms for clearing infection and thus protecting themselves against disease than penaeid shrimp. These abilities were particularly evident here with a WSSV strain of lower apparent virulence. However, when challenged with a strain of higher virulence or with high doses of the low virulent strain, similar numbers of infected cells are established as in the more susceptible Penaeus vannamei challenged using identical conditions. This finding clearly indicates that once some acute infection load threshold has been passed, whatever defense mechanisms are mounted by $M$. rosenbergii become swamped, and the clinical outcome of disease through to mortality progresses similarly to that in shrimp with acute infection. The dose and strain variables assessed in this study are likely to explain in part why differences in the susceptibility of juvenile $M$. rosenbergii have been reported, and highlight the importance of using well-characterized WSSV strains and standardized challenge conditions. $M$. rosenbergii and other palaemonid prawns can serve as useful model crustaceans for understanding anti-WSSV protection mechanisms and how these might be primed to protect these and cultured penaeid shrimp against disease caused by WSSV and other problematic viruses.

Acknowledgements. M.C. was supported by a scholarship from the Institute for the Promotion of Innovation Through Science and Technology in Flanders (IWTVlaanderen, Belgium) and J.J.D.L. was supported by the Foundation for Science and Technology (FCT, Portugal). The authors thank J. Desmyter and T. Q. Thai for helping with prawn cultures. We also thank the reviewers and editor for their useful comments which improved the quality of this paper.

\section{LITERATURE CITED}

Bonami JR, Widada JS (2011) Viral diseases of the giant fresh water prawn Macrobrachium rosenbergii: A review. J Invertebr Pathol 106:131-142

Cambi A, Koopman M, Figdor CG (2005) How C-type lectins detect pathogens. Cell Microbiol 7:481-488

Cerenius L, Jiravanichpaisal P, Liu HP, Söderhäll I (2010) Crustacean immunity. In: Söderhäll K (ed) Invertebrate immunity. Landes Bioscience and Springer Science + Business Media, p 241-245

Escobedo-Bonilla CM, Wille M, Alday Sanz V, Sorgeloos P, Pensaert MB, Nauwynck HJ (2005) In vivo titration of white spot syndrome virus (WSSV) in specific pathogenfree Litopenaeus vannamei by intramuscular and oral routes. Dis Aquat Org 66:163-170

Escobedo-Bonilla CM, Audoorn L, Wille M, Alday-Sanz V, Sorgeloos P, Pensaert MB, Nauwynck HJ (2006) Standardized white spot syndrome virus (WSSV) inoculation procedures for intramuscular or oral routes. Dis Aquat Org 68:181-188

Escobedo-Bonilla CM, Wille M, Alday Sanz V, Sorgeloos P, Pensaert MB, Nauwynck HJ (2007) Pathogenesis of a Thai strain of white spot syndrome virus (WSSV) in juvenile, specific pathogen-free Litopenaeus vannamei. Dis Aquat Org 74:85-94

Escobedo-Bonilla CM, Alday-Sanz V, Wille M, Sorgeloos P, Pensaert MB, Nauwynck HJ (2008) A review on the morphology, molecular characterization, morphogenesis and pathogenesis of white spot syndrome virus. J Fish Dis 31: 1-18 
FAO (Food and Agriculture Organization of the United Nations) (2009) FIGIS: Fisheries Global Information System. FAO Fisheries and Aquaculture Department. Accessed: 30 Jan 2012. www.fao.org/fishery/figis/en

> Flegel TW (2007) Update on viral accommodation, a model for host-viral interaction in shrimp and other arthropods. Dev Comp Immunol 31:217-231

> Hasson KW, Lightner DV, Mohney LL, Redman RM, Poulos BT, White BM (1999) Taura syndrome virus (TSV) lesion development and the disease cycle in the Pacific white shrimp Penaeus vannamei. Dis Aquat Org 36:81-93

> Jiravanichpaisal P, Bangyeekhun E, Söderhäll K, Söderhäll I (2001) Experimental infection of white spot syndrome virus in freshwater crayfish Pacifastacus leniusculus. Dis Aquat Org 47:151-157

Lo CF, Ho CH, Peng SE, Chen CH and others (1996) White spot syndrome baculovirus (WSBV) detected in cultured and captured shrimp, crabs and other arthropods. Dis Aquat Org 27:215-225

Luo T, Zhang X, Shao Z, Xu X (2003) PmAV, a novel gene involved in virus resistance of shrimp Penaeus monodon. FEBS Lett 551:53-57

Ma THT, Tiu SHK, He JG, Chan SM (2007) Molecular cloning of a C-type lectin (LvLT) from the shrimp Litopenaeus vannamei: Early gene down-regulation after WSSV infection. Fish Shellfish Immunol 23:430-437

Ma THT, Benzie JAH, He JG, Chan SM (2008) PmLT, a Ctype lectin specific to hepatopancreas is involved in the innate defense of the shrimp Penaeus monodon. J Invertebr Pathol 99:332-341

New MB (2002) Farming freshwater prawns: a manual for the culture of the giant river prawn (Macrobrachium rosenbergii). FAO Fish Tech Pap 428. FAO, Rome

Pais R, Shekar M, Karunasagar I, Karunasagar I (2007) Hemagglutinating activity and electrophoretic pattern of hemolymph serum proteins of Penaeus monodon and Macrobrachium rosenbergii to white spot syndrome virus injections. Aquaculture 270:529-534

Peng SE, Lo CF, Ho CH, Chang CF, Kou GH (1998) Detection of white spot baculovirus (WSBV) in giant freshwater prawn, Macrobrachium rosenbergii, using polymerase chain reaction. Aquaculture 164:253-262

> Pramod Kiran RB, Rajendran KV, Jung SJ, Oh MJ (2002) Experimental susceptibility of different life-stages of the giant freshwater prawn, Macrobrachium rosenbergii (de Man), to white spot syndrome virus (WSSV). J Fish Dis 25:201-207

Rahman MM, Escobedo-Bonilla CM, Corteel M, DantasLima JJ and others (2006) Effect of high water temperature $\left(33^{\circ} \mathrm{C}\right)$ on the clinical and virological outcome of experimental infections with white spot syndrome virus (WSSV) in specific pathogen-free (SPF) Litopenaeus vannamei. Aquaculture 261:842-849

Rahman MM, Corteel M, Wille M, Alday-Sanz V, Pensaert MB, Sorgeloos P, Nauwynck HJ (2007) The effect of raising water temperature to $33^{\circ} \mathrm{C}$ in Penaeus vannamei juveniles at different stages of infection with white spot syndrome virus (WSSV). Aquaculture 272:240-245

Rahman MM, Corteel M, Escobedo-Bonilla CM, Wille M and others (2008) Virulence of white spot syndrome virus
(WSSV) isolates may be correlated with the degree of replication in gills of Penaeus vannamei juveniles. Dis Aquat Org 79:191-198

> Rajendran KV, Vijayan KK, Santiago TC, Krol RM (1999) Experimental host range and histopathology of white spot syndrome virus (WSSV) infection in shrimp, prawns, crabs and lobsters from India. J Fish Dis 22: 183-191

Sahul Hameed AS, Charles MX, Anilkumar M (2000) Tolerance of Macrobrachium rosenbergii to white spot syndrome virus. Aquaculture 183:207-213

> Sarathi M, Ishaq Ahmed VP, Venkatesan C, Balasubramanian G, Prabavathy J, Sahul Hameed AS (2007) Comparative study on immune response of Fenneropenaeus indicus to Vibrio alginolyticus and white spot syndrome virus. Aquaculture 271:8-20

Sarathi M, Nazeer Basha A, Ravi M, Venkatesan C, Senthil Kumar B, Sahul Hameed AS (2008) Clearance of white spot syndrome virus (WSSV) and immunological changes in experimentally WSSV-injected Macrobrachium rosenbergii. Fish Shellfish Immunol 25: 222-230

Shelby KS, Popham HJR (2006) Plasma phenoloxidase of the larval tobacco budworm, Heliothis virescens, is virucidal. J Insect Sci 6:1-12

Song YL, Yu CI, Lien TW, Huang CC, Lin MN (2003) Haemolymph parameters of Pacific white shrimp (Litopenaeus vannamei) infected with Taura syndrome virus. Fish Shellfish Immunol 14:317-331

> van Hulten MCW, Reijns M, Vermeesch AMG, Zandbergen F, Vlak JM (2002) Identification of VP19 and VP15 of white spot syndrome virus (WSSV) and glycosylation status of the WSSV major structural proteins. J Gen Virol 83:257-265

Waikhom G, John KR, George MR, Jeyaseelan MJP (2006) Differential host passaging alters pathogenicity and induces genomic variation in white spot syndrome virus. Aquaculture 261:54-63

Wang XW, Xu WT, Zhang XW, Zhao XF, Yu XQ, Wang JX (2009) A C-type lectin is involved in the innate immune response of Chinese white shrimp. Fish Shellfish Immunol 27:556-562

> Wei X, Liu X, Yang J, Fang J, Qiao H, Zhang Y, Yang J (2012) Two C-type lectins from shrimp Litopenaeus vannamei that might be involved in immune response against bacteria and virus. Fish Shellfish Immunol 32: $132-140$

> Yoganandhan K, Syed Musthaq S, Sudhakaran R, Balasubramanian G, Sahul Hameed AS (2006) Temporal analysis of VP28 gene of Indian white spot syndrome virus strain (WSSV) in different crustacean hosts. Aquaculture 253: 71-81

Z Zhao ZY, Yin ZX, Xu XP, Weng SP and others (2009) A novel C-type lectin from the shrimp Litopenaeus vannamei possesses anti-white spot syndrome virus activity. J Virol 83:347-356

Zwart MP, Dieu BTM, Hemerik L, Vlak JM (2010) Evolutionary trajectory of white spot syndrome virus (WSSV) genome shrinkage during spread in Asia. PLoS ONE 5: e13400
Editorial responsibility: Jeff Cowley, Brisbane, Queensland, Australia
Submitted: February 22, 2012; Accepted: June 25, 2012

Proofs received from author(s): August 24, 2012 